\title{
HMGA2/LPP Short Fusion Gene
}

National Cancer Institute

\section{Source}

National Cancer Institute. HMGA2/LPP Short Fusion Gene. NCI Thesaurus. Code C99419.

A fusion gene that results from a chromosomal translocation $\mathrm{t}(3 ; 12)(\mathrm{q} 27-28 ; \mathrm{q} 15)$ which fuses exons 1-3 of the HMGA2 gene to exons 9-11 of the LPP gene. This rearrangement is associated with solitary lipoma, soft tissue chondroma, pulmonary chondroid hamartoma and parosteal lipoma. 